\title{
'What?' Speaking and Language out Aloud. With Reference to the Prologue of Romeo and Juliet
}

\author{
Andrew Wade
}

\section{(2) OpenEdition}

\section{Journals}

\section{Electronic version}

URL: http://journals.openedition.org/shakespeare/1285

DOI: 10.4000/shakespeare.1285

ISSN: 2271-6424

\section{Publisher}

Société Française Shakespeare

\section{Printed version}

Date of publication: 1 November 1994

Number of pages: 235-237

\section{Electronic reference}

Andrew Wade, «'What?' Speaking and Language out Aloud. With Reference to the Prologue of Romeo and Juliet », Actes des congrès de la Société française Shakespeare [Online], 12 | 1994, Online since 01 January 2007, connection on 06 May 2019. URL : http://journals.openedition.org/shakespeare/1285 ; DOI : 10.4000/shakespeare.1285 
COSMOPOLITISME ET INSULARITÉ 


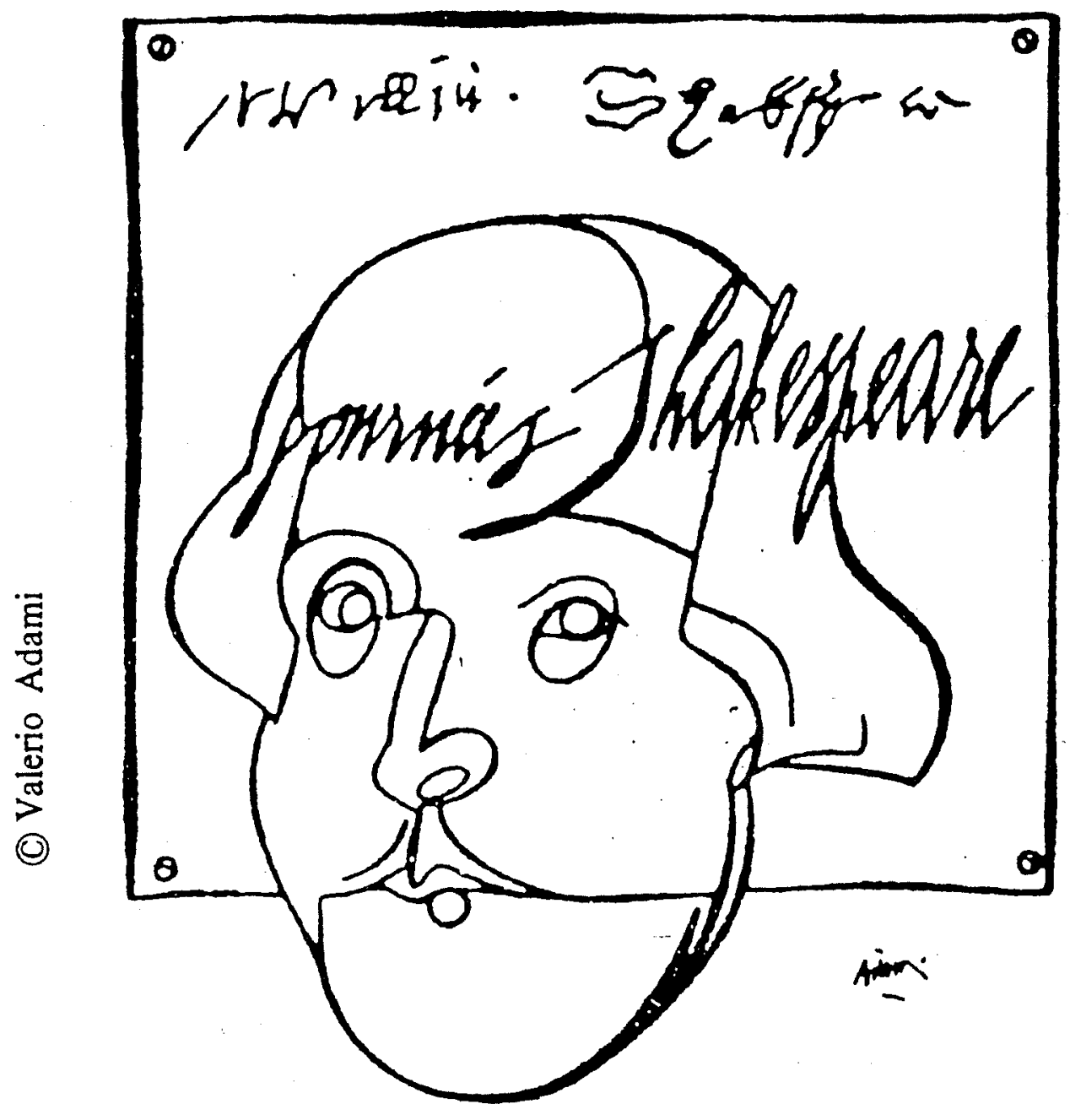

Affiche de Valerio Adami, spécialement conçue pour les journées Shakespeare 1979 


\section{SHAKESPEARE}

COSMOPOLITISME ET INSULARITÉ

Société Française Shakespeare

Actes du Congrès 1993

sous la direction

de

M. T. JONES-DAVIES

Ouvrage publié avec le soutien de

BARCLAYS

BARCLAYS BANK S.A

PARIS

LES BELLES LETTRES

1994 
Tous droits de traduction, de reproduction et d'adaptation réservés pour tous les pays.

(C) 1994 Société d'édition Les Belles Lettres, 95 bd Raspail 75006 Paris

ISBN 2.251.69122-7 


\title{
«What?» Speaking the language out aloud. With reference to the Prologue in Romeo and Juliet
}

\author{
The following is an attempt to briefly write up the practical \\ Workshop.
}

Voice Work in the Royal Shakespeare Company is essentially a practical approach to speaking the text. Discovering the meaning by speaking out aloud rather than as a result of academic analysis. My aim in the Workshop was to give a brief insight into this (often very private) exploratory work between the voice coach and the actor.

In many ways, the work aims to form a bridge between painstaking analysis of the text and finding ways whereby the language connects with the actor personally. Not only intellectually understanding but finding the need for those particular words in order to define the human situation verbally.

This area of the company's work needs to be seen as a part of the whole picture in the development of a production. In no way does it deal in the 'right' or 'wrong' way of speaking Shakespeare's language, but in choices for the actor. Yet, the final product must overwhelm Shakespeare's status as a national and international 'institution'. It must live and it must challenge in performance. Bob Allen's A School Perspective on Shakespeare Teaching gives an amusing, if extreme, idea of what we may be up against.

A group of volunteers bravely agreed to take part and, by way of focusing their attention and trying to help them forget that they were being watched, I led them through some basic voice work.Initially, to look at what the physical sensations of tension and relaxation are, then identifying areas of the body where this tension affects the voice and how to undo these 'holding' areas particularly shoulders and neck. We demonstrated how this can be linked to holding the breath. Moving on then to breathing opening out the ribs to free them and finding the breath as 'deep' 
inside as possible - so that the breath is always ready. This allows an active use of the outgoing breath and the participants were able to feel that the energy for speaking is the breath. We then explored our individual resonances as the breath is tuned into vibrations of sound and how to mould that sound into shapes. Once some time had been spent 'tuning into' each individual's voice, and its potential and awareness of consciously defining sounds, I introduced the group to Shakespeare's words.

\section{The PROLOGUE - ROMEO \& JULIET.}

\section{Chorus :}

Two households, both alike in dignity In fair Verona, where we lay our scene, From ancient grudge break to new mutiny, Where civil blood makes civil hands unclean. From forth the fatal loins of these two foes A pair of star-crossed lovers take their life ; Whose misadventured piteous overthrows

Doth with their death bury their parents' strife.

The fearful passage of their death-marked love And the continuance of their parents' rage,

Which, but their children's end, naught could remove, Is now the two hours' traffic of our stage ;

The which if you with patient ears attend;

What here shall miss, our toil shall strive to mend.

I invited the volunteers to walk around and speak the text immediately and out loud (as opposed to reading it first). Following this, we put the text face down on the floor and 'called out' which words they remembered - e.g. star-crossed, mutiny. They described their choice of words as being those that were 'strong', 'fun', 'tasty', 'aggressive'. Reading the piece again all together they gestured on those words previously remembered. This opened up a discussion about how we 'attend' to language when we speak - how often we phrase in an arc and lose the specific contribution and dynamic of each word.

We next explored the piece for sounds only - the different characteristics - long and short vowels, the smoothness of some consonants versus the explosion of others - how the words are shaped muscularly. 
All the time the focus is off the literal, logical sense and directed towards finding ways to free the language. Moving from left brain towards using the right !

Time was then spent on the thoughts - how they build, how one thought leads to the next to create a cumulative impression, yet still contained within the sonnet shape. How the sense fits into the poetic shape. We debated how an actor wants to 'feel real' with language - not simply speaking a 'poetic effect'. This led to discussion that thought-motive-action are all through the words. How, in the sonnet, it would be difficult to leave anything out without the 'whole' being lost. That really the sonnet is a perfect 'play-within-a-play' and takes us absolutely into the world of the play itseslf.

The exercises are primarily physically based in order to :

a) keep making the connection with words in the body

b) distract the mind from being solely in charge.

Therefore, speaking out aloud to define what is being felt and thought. Finding ways for the words to spring from somewhere else other than purely cerebrally. To embrace shape and confront Louis MacNeice's phrase that «the shape is half the meaning».

Voice work invites the actor to go a little beyond what feels safe, in order to discover something new and personal about those words.

With thanks to my brave volunteers !

Andrew WADE

Head of Voice

The Royal Shakespeare Theatre 